Original Research Paper

\title{
Budidaya Tanaman Pakcoy (Brassica Rapa Subsp. Chinensis) Dengan Teknik Vertikultur Pada Lahan Sempit Di Kelurahan Penaraga Kecamatan Raba Kota Bima
}

\author{
Maya Mardilla $^{1^{*}}$, Aci Pratiwi ${ }^{2}$ \\ ${ }^{1,2}$ Program Studi Pendidikan Guru Sekolah Dasar(PGSD), Fakultas Keguruan Dan Ilmu Pendidikan, Universitas \\ Mataram, Mataram, Indonesia
}

DOI: https://doi.org/10.29303/jpmpi.v3i2.537

Sitasi: Mardilla, M., \& Pratiwi (2021). Budidaya Tanaman Pakcoy (Brassica Rapa Subsp. Chinensis) Dengan Teknik Vertikultur Pada Lahan Sempit Di Kelurahan Penaraga Kecamatan Raba Kota Bima . Jurnal Pengabdian Magister Pendidikan IPA, 4(1)

\section{Article history}

Received: 02 Desember 2020

Revised: 29 Desember 2020

Accepted: 08 Januari 2020

*Corresponding Author: Maya Mardilla, Program Studi Pendidikan Guru Sekolah Dasar, Fakultas Keguruan Dan Ilmu Pendidikan, Universitas Mataram, Mataram, Indonesia Email:

mayamardilla09@gmail.com

\begin{abstract}
Teknik vertikultur adalah metode yang digunakan bagi pemukiman masyarakat yang memiliki lahan sempit secara optimal. Teknik ini akan menyusun tanaman secara bertingkat dari atas kebawah dengan jenis tanaman yang beragam. Penyusunan bisa dilakukan dengan mengikat menggunakan tali atau kawat di pagar, ataupun bisa di gantungkan kebambu menggunakan tali yang kuat dari atas kebawah. Teknik ini bisa pergunakan oleh segala kalangan, karena budgetnya relatif murah dibanding teknik lain. Yang membuat murah dari teknik ini adalah penggunaan alat dari barang bekas seperti botol, kaleng, dan sebagainya. Tujuan dari program ini adalah untuk meningkatkan mutu dan kualitas pangan di daerah tersebut. Salah satu cara yang dapat diterapkan, dengan memberikan edukasi kepada masyarakat Kelurahan Penaraga mengenai pemanfaatan lahan sempit dengan teknik vertikultur pada budidaya pakcoy. Dari program tersebut diharapkan masyarakat dapat terbantu untuk memenuhi kebutuhan panganya, sekaligus dapat meningatkan imunitas tubuh anggota keluarga, serta mengurangi pengeluaran masyarakat. Program ini menggunakan metode kualitatif dengan pendekatan kualitatif deskriptif. Sedangkan untuk pengolahan data dianalisis dengan cara penyajian data dan penarikan kesimpulan atau verifikasi. Hasil dari program pemberdayaan masyarakat ini adalah terbentuknya masyarakat berkualitas yang mampu membudidayakan tanaman pakcoy melalui teknik vertikultur sehingga dapat menghasilkan bahan pangan organik dari pekarangannya sendiri dan sadar akan pentingnya mematuhi protokol kesehatan pada saat pandemi Covid-19.
\end{abstract}

Keywords: Pakcoy; Teknik Vertikultur; Lahan Sempit; Kelurahan Penraga; Covid-19.

\section{Pendahuluan}

Mewabahnya penyakit Covid-19 (Novel corona viruses disease 2019) saat ini di seluruh wilayah Indonesia termasuk di Kota Bima, dan belum ada obatnya menyebabkan rantai penyebarannya semakin meluas. Pandemi Covid-
19 menyebabkan lemahnya berbagai sektor penting pembangunan termasuk sektor pangan. Melemahnya ketahanan pangan di beberapa wilayah di Indonesia khususnya Kota Bima menyebabkan kebutuhan pangan kurang tercukupi.

Berdasarkan pola penggunaan tanah, lahan sawah di Kota Bima mencapai 1.923 ha yang terdiri sawah irigasi seluas 1.825 ha dan sawah 
tadah hujan seluas 98 ha. Sedangkan tanah tegalan/kebun mencapai 3.623 ha, ladang/huma seluas 1.225 ha dan kawasan hutan negara seluas 9.421 ha. Komoditas andalan pertanian terdiri dari padi, jagung, kedelai dan kacang tanah. Sedangkan komoditas unggulan perkebunan meliputi: serikaya, kelapa, asam, kemiri, jambu mete, wijen dan kapuk. Komoditas pertanian dan perkebunan seperti pakcoy masih kurang padahal sayuran tersebut merupakan salah satu sayuran yang memiliki berbagai macam kandungan gizi yang memberikan manfaat bagi kesehatan dan juga minat masyarakat terhadap sayuran tersebut sangat tinggi.

Pakcoy sendiri merupakan sayuran dengan nama latin Brassica rapa subsp. chinensis . Sayuran ini memiliki daun yang halus, tidak berbulu dan tidak membentuk krop. Tangkai daunnya lebar dan kokoh, tulang daun dan daunnya mirip dengan sawi hijau, namun daunnya lebih tebal dibandingkan dengan sawi hijau Jika pun masyarakat berminat untuk menanam sayuran tersebut, mereka terkendala oleh keterbatasan lahan yaitu lahan pekarangan rumah yang sempit.

Hal ini juga yang menjadi masalah di Kelurahan Penaraga Kecamatan Raba Kota Bima Nusa Tenggara Barat, dimana masyarakat memiliki minat untuk menanam sayuran pakcoy namun karena keterbatasan lahan serta minimnya budget menjadikan minat dari masyarakat kurang terealisasikan. Gambaran umum masyarakat di wilayah ini yaitu rata-rata berprofesi menjadi pedagang, bisa dihitung menggunakan jari yang berprofesi sebagai pegawai. Dalam hal ini bisa dikatakan rata-rata masyarakat memiliki pendapatan yang hanya cukup untuk memenuhi kebutuhan sehari-hari.. Keadaan lingkungan di wilayah ini pun terlihat sempit, ini dikarenakan karena gang-gangnya kebanyakan hanya bisa dilewati motor, dan

sepeda saja. Sedangkan gang yang bisa dilewati mobil hanya di gang ompu lewi. Kondisi perkarangan rumah di RT 03 ini kebanyakan memiliki lahan yang sempit, dan karena itupun jarang terlihat masyarakat menanam tanaman seperti sayur mayur diperkarangan rumahnya. Kebanyakan mereka hanya menanam bunga dalam pot saja, kadang ada yang digantungkan.

Berdasarkan kenyataan diatas kami mengusulkan solusi untuk melakukan budidaya tanaman pakcoy (Brassica rapa subsp. Chinensis) secara vertikultur di lahan sempit dengan memanfaatkan botol bekas. Vertikultur yaitu sebuah metode penanaman secara vertikal yang umumnya menggunakan pipa sebagai media tanam. Namun dalam hal ini penulis memilih metode vertikultur menggunakan media tanam berupa botol bekas sebagai upaya pemanfaatan limbah plastik rumah tangga sehingga menghemat pengeluaran biaya. Pemilihan metode vertikultur karena metode tersebut efektif digunakan pada lahan pekarangan rumah yang sempit atau bahkan tidak memiliki lahan sekalipun. Program memanfaatkan lahan pekarangan dengan menanam sayuran sebagai upaya mendukung pemenuhan kebutuhan pangan keluarga sejalan dengan salah satu strategi Kementerian Pertanian RI menghadapi pandemi Covid-19 adalah mengoptimalkan lahan pekarangan dengan tanaman pangan untuk kebutuhan pangan keluarga. Ketahanan pangan keluarga di saat dan pasca pandemi Covid-19 menjadi semakin penting untuk mendukung ketersediaan pangan yang cukup yang bertujuan untuk memenuhi kebutuhan pangan sekaligus untuk meningatkan imunitas tubuh anggota keluarga, serta mengurangi pengeluaran untuk membeli bahan pangan bagi masyarakat.

\section{Metode}

\section{Waktu dan tempat}

Program ini dilakukan di RT 03 RW 02 Kelurahan Penaraga Kecamatan Raba Kota Bima Nusa Tenggara Barat pada bulan Desember s/d Januari 2021.

\section{Alat dan Bahan}

Bahan yang dibutuhkan dalam program ini berupa bibit pakcoy, tanah topsoil, kompos, dedak, pakan ikan, gula merah dan yakult. Alat yang digunakan dalam program ini adalah botol bekas, tali yang kuat, paku untuk menggantung botol, gunting dan pisau cutter serta peralatan protokol kesehatan pada saat pandemic Covid-19 yaitu masker, handsanitizer, dan brosur $3 \mathrm{M}$ protokol kesehatan.

\section{Bentuk kegiatan}

Bentuk kegiatan dalam program budidaya tanaman pakcoy (Brassica rapa subsp. chinensis) secara vertikultur pada lahan sempit dengan memanfaatkan botol bekas adalah 1) 
Penyuluhan tentang budidaya pakcoy menggunakan metode vetikultur dengan memanfaatkan botol bekas , 2) Persiapan alat dan bahan, 2) Persiapan wadah tanam (botol bekas), 3) pemilihan benih tanam , 4) Pembuatan instalasi vertikultur, 5) tahapan penanaman, 6) pembagian Perawatan dan Pemeliharaan, 7) Persiapan alat dan bahan untuk pembuatan pupuk cair, 8) Pembagian pupuk cair, 9) Panen dan pasca panen, 10) Melakukan kegiatan sosialisasi protokol kesehatan anti Covid-19, (11) Monitoring dan evaluasi.

\section{Metode}

Program ini menggunakan metode kualitatif dengan pendekatan kualitatif deskriptif karena mampu menyajikan gambaran secara detail tentang suatu situasi, selanjutnya pendekatan kualitatif itu umumnya merupakan data yang dikumpulkan berupa kata-kata, gambar dan bukan angka. Pengambilan data pada program ini dilakukan dengan tehnik observasi lapangan, wawancara dan studi pustaka yang selanjutnya dianalisis dengan melakukan penarikan kesimpulan.

\section{Hasil dan Pembahasan}

Program budidaya tanaman pakcoy (Brassica rapa subsp. Chinensis) secara vertikultur pada lahan sempit dengan memanfaatkan botol bekas di RT 03 RW 02 Kelurahan Penaraga Kecamatan Raba Kota Bima dalam rangka pemberdayaan masyarakat kota dilakukan secara terstruktur dan melibatkan masyarakat secara langsung. Program ini merangkum tiga kegiatan yang berbeda dan bertujuan sekaligus untuk membantu memenuhi kebutuhan pangan masyarakat dengan memanfaatkan lahan sempit dan limbah rumah tangga berupa botol plastik, serta pencegahan penyebaran Covid-19 di Kelurahan Penaraga.

1. Budidaya tanaman pakcoy secara vertikultur pada lahan sempit dengan memanfaatkan botol bekas. Tahapan kegiatan dari program ini yaitu :

a. Persiapan Wadah Tanam (Botol Bekas)
- Cuci bersih botol dengan menggunakan air bersih.

- Sayat bagian botol dari mulai bagian bawah leher botol hingga bagian dasar botol.

- Sayatan dibuat dengan bentuk persegi panjang dengan lebar 3-5 cm dan panjang disesuaikan dengan panjang botol.

- Lubangi bagian atas dan bawah botol untuk tempat memasukkan tali, dan tidak lupa untuk membuat lubang-lubang dibagian bawah botol untuk sirkulasi air.

- Isi botol dengan media tanam yang dikehendaki.

- Masukkan media tanam hingga penuh, kemudian letakkan ditempat yang sejuk untuk selanjutnya di lakukan penanaman benih.

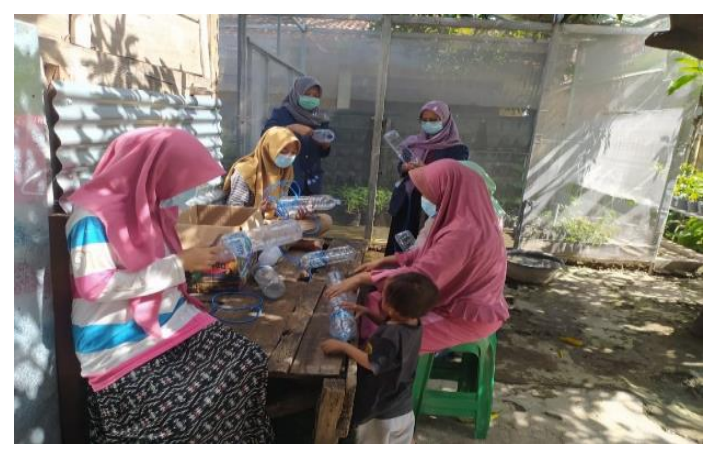

Gambar 1. Persiapan Media Tanam

b. Pemilihan Benih Tanam

Sebelum melakukan persemaian benih, yang harus dilakukan terlebih dahulu yaitu memilih benih sebab benih dengan kualitas yang unggul akan menghasilkan hasil panen yang berkualitas. Berikut hal yang harus diperhatikan :

Pilihlah toko yang mempunyai reputasi yang baik dan terpercaya.

Benih unggul yang sudah mendapatkan label sertifikat resmi dan tidak dalam masa dekat kadaluwarsa.

Memilih benih, pastikan benih disimpan ditempat yang sejuk dan tidak terpapar 
sinar matahari langsung atau suhu yang tinggi. Sebelum disemai, benih terlebih dahulu direndam dalam air panas, pilah benih yang tenggelam dan mengambang. Benih yang mengambang sebaiknya dibuang sehingga yang digunakan hanya benih yang tenggelam.

Pada tahap persemaian yang harus dilakukan yaitu menggunakan wadah khusus semai yang disebut pot tray dengan jumlah lubang 35 (jumlah dan ukuran lubang bisa dipilih tergantung kebutuhan). Dipilihnya wadah pot tray karena wadah ini dapat diisi dengan media tanam yaitu tanah topsoil yang dicampur dengan kompos sehingga bersifat organik dan memiliki lubang yang berada di bagian bawah untuk sirkulasi air. Setiap lubang pot tray umumnya diisi dengan 1 benih namun bisa juga diisi dengan 2 atau 3 benih.

Sebelum memindahkan benih, basahi terlebih dahulu media tanam yang ada di dalam pot tray, setelah itu baru taburkan benih. Tutup wadah semai dengan plastik bening yang diberi 2 - 8 lubang. Ketika benih mulai berkecambah, buka tutup plastiknya serta jaga medianya agar tidak kering dan tidak terlalu basah. Semprotkan air halus 1-2 kali sehari bila medianya kering. Benih mulai bertunas dalam waktu 3 - 5 hari. Persemaian diakhiri setelah memiliki 2 - 7 helai daun.

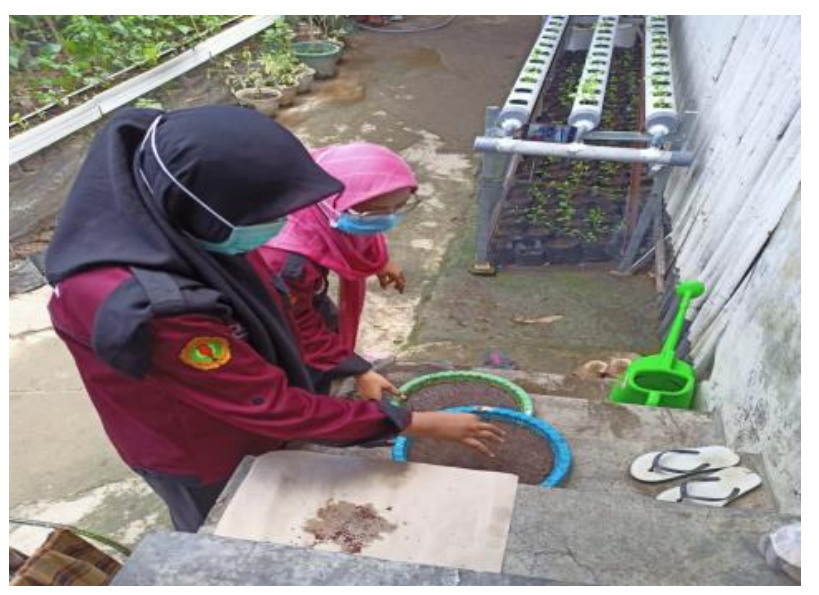

Gambar 2. Semai bibit pakcoy c. Pembuatan Instalasi Vertikultur

Lokasi untuk meletakkan wadah botol bekas yang berisi tanaman harus disiapkan untuk instalasi vertikultur budidaya tanaman sayuran. Sesuai dengan tujuan program ini yaitu untuk memanfaatkan lahan sempit, maka lokasi yang digunakan yaitu dinding bagian depan, samping, maupun belakang rumah, bisa juga menggunakan pagar rumah. Cukup menggantungkan botol ke bagian tembok.

Kemudian agar wadah botol tetap telihat rapi dan mendapatkan nilai estetika yang baik, wadah botol harus diatur sedemikian rupa agar visualnya menarik dipandang mata. Penting sekali untuk memerhatikan lokasi dengan pencahayaan matahari yang cukup agar tanaman terutama sayuran hijau dapat tumbuh dengan baik.

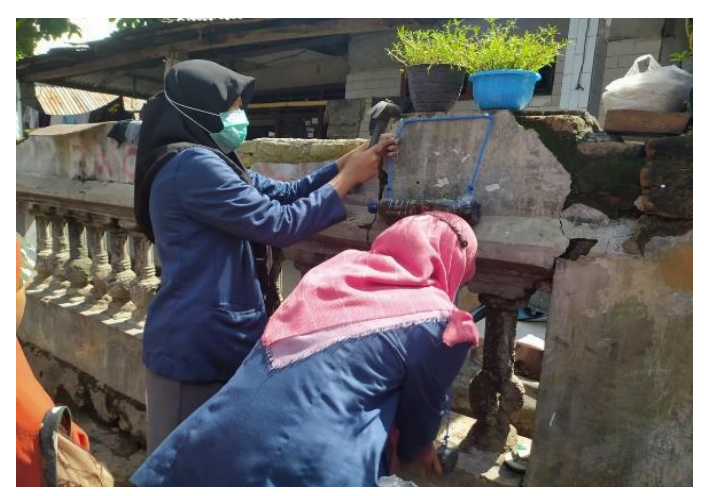

Gambar 3. Instalasi wadah tanam

d. Tahapan Penanaman

Penanaman dilakukan dengan cara menanamkan bibit tanaman ke wadah botol bekas dengan 2 bibit dalam satu botol. Sebelum bibit-bibit ditanam di wadah botol, terlebih dahulu siramkan air pada media tanam hingga jenuh, ditandai dengan menetesnya air keluar dari lubang-lubang tanam. Setelah cukup, baru mulai menanam bibit satu demi satu. Pastikan semua bagian akar dari setiap bibit masuk ke dalam tanah. Penanaman dapat dilakukan pada pagi atau sore hari agar tanaman mudah beradaptasi. 


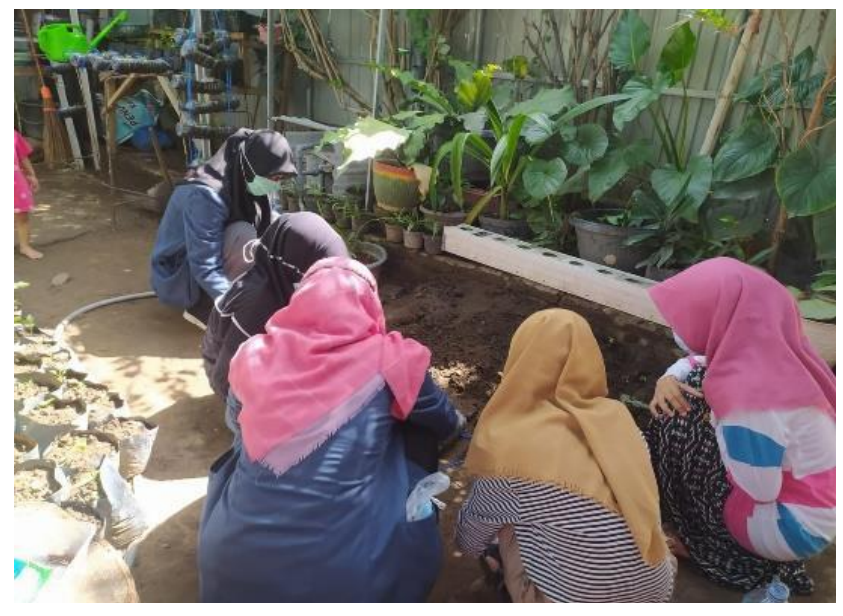

Gambar 3. Penanaman

e. Perawatan dan Pemeliharaan

Pemberian pupuk cair ini diberikan minimal 1 kali dalam seminggu. Tapi karena cuaca memburuk, untuk menyelamatkan tumbuhan agar bisa tumbuh. Pemberian pupuk cair minimal 2 atau 3 kali dalam seminggu.

Pupuk cair yang digunakan ini adalah pupuk cair organik. Yang dimana kami membuatnya sendiri, dengan alat dan bahan yang di sediakan dengan mudah. Alat yang kami gunakan adalah ember besar dan pengaduk berupa bambu panjang. Sedangkan bahan yang kami gunakan adalah yakult 1 bungkus isi 5 botol, dedak $1 \mathrm{~kg}$, pakan ikan $1 \mathrm{~kg}$, gula merah cor $1 \mathrm{~kg}$, dan air 20 Liter.

Proses pembuatannya pun mudah, dimana dengan mencampurkan semua bahan-bahan tersebut di ember. Setelah itu aduk perlahan sampai merata. Terakhir simpan ember yang berisi pupuk tersebut di tempat yang jauh dari jangkauan anak-anak, agar tidak dimainkan dan difermentasikan hingga 15 hari. Setelah 15 hari pupuk sudah jadi, dan siap dipakai. Selain di pakai sendiri, pupuk ini juga kami bagikan ke masyarakat. Dimana kami membagikan seluruh rumah yang menjadi target kami, yaitu 8 rumah. Masing rumah, mendapatkan pupuk 1 botol yang berisi $600 \mathrm{ml}$.
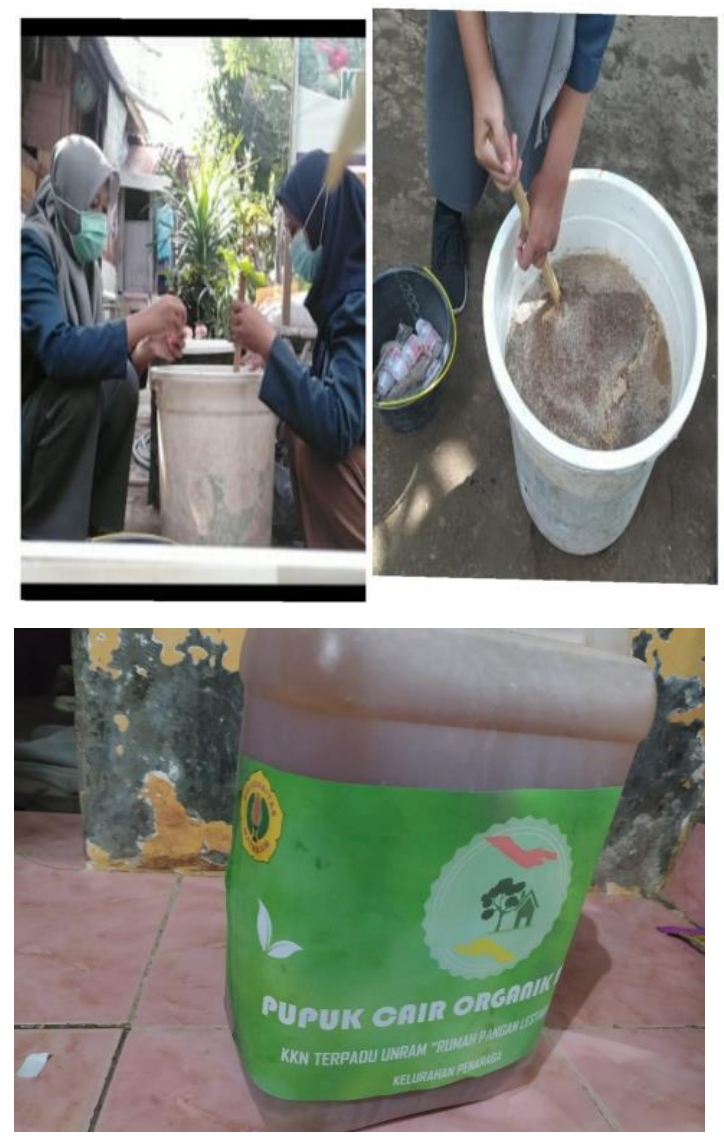

Gambar 5. Produk pupuk cair organic

f. Panen dan Pasca Panen

Umur panen untuk jenis sayuran daun yaitu berkisar 21-25 hari setelah tanam. Atau juga dapat menggunakan kriteria tinggi tanaman jika sudah mencapai tinggi maksimal antara $20-25 \mathrm{~cm}$ maka dapat langsung di panen. Cara panen yaitu dengan mencabut seluruh tanaman atau hanya memotong batang pakcoy. Karena program ini diperuntukan untuk memenuhi kebutuhan pangan masyarakat maka panen menggunakan metode memotong batang sesuai kebutuhan yang menanam agar dapat dipanen berulang kali. Sayur yang telah dipanen sebaiknya segera dikonsumsi, karena sayur hanya akan bertahan 3-4 hari di lemari pendingin. Tanaman yang terlebih dahulu ditanam yaitu tanaman contoh sebagai gambaran nyata program ini sehingga tanaman contoh terlebih dahulu mencapai masa panen, baru kemudian dilakukan 
sosialisasi kepada masyarakat sehingga saat ini tanaman yang ada pada masyarakat masih berumur remaja.
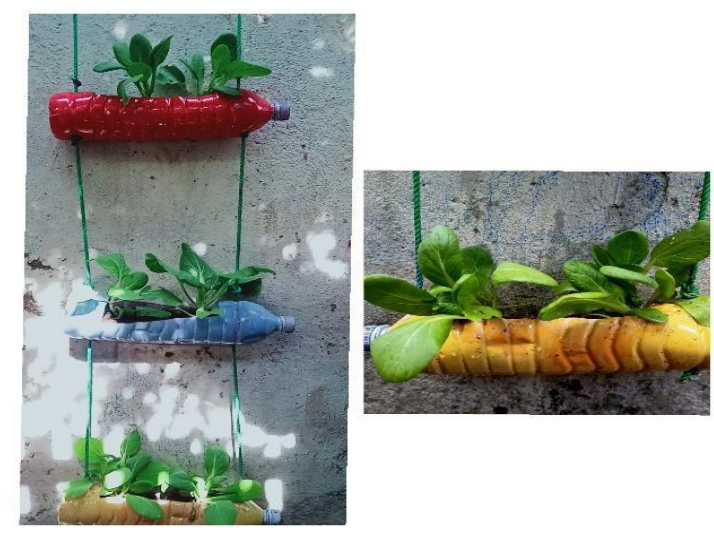

Gambar 6. Tanaman contoh siap panen
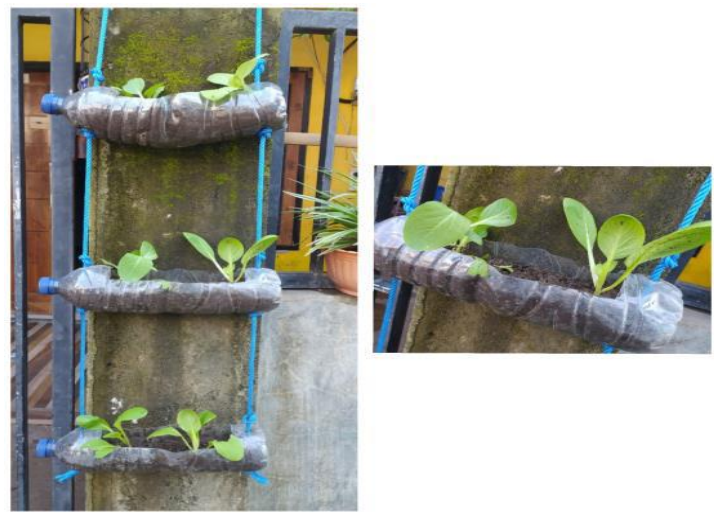

Gambar 7. Tanaman pada masyrakat yang masih berumur remaja

2. Sosialisasi Covid-19

Sembari kami menjalankan program penerapan metode vertikultur di perkarangan rumah yang sempit, kami menjalankan program kedua yaitu sosialisi covid-19. Program ini bertujuan untuk mengingatkan masyarakat khususnya di Kelurahan Penaraga RT 02 RW 03 bagaimana bahayanya covid-19 dan penularanya. Selain itu dapat menanamkan kepada masyarakat bagaimana pencegahan covid dengan benar dan simpel.

Cara kami bersosialisasi ini dengan mengingatkan masyarakat bahwa hidup dipendemik ini harus ingat akan praktik 3M (Menggunakan masker, Mencuci Tangan, dan Menjaga Jarak). Upaya praktik 3M tersebut untuk memutuskan mata rantai penularan Covid-19.

Penjelasan tentang $3 \mathrm{M}$ tersebut kami utarakan lewat penempelan browsur di tiap halaman rumah warga, dan tidak lupa kami membagikan masker gratis. Sebelum berkegiatanpun seperti sosialisasi teknik vertikultur, pembuatan media tanam bersama-sama, dan sebagainya kami tidak lupa menyuruh masyarakat untuk mematuhi protokol kesehatan.

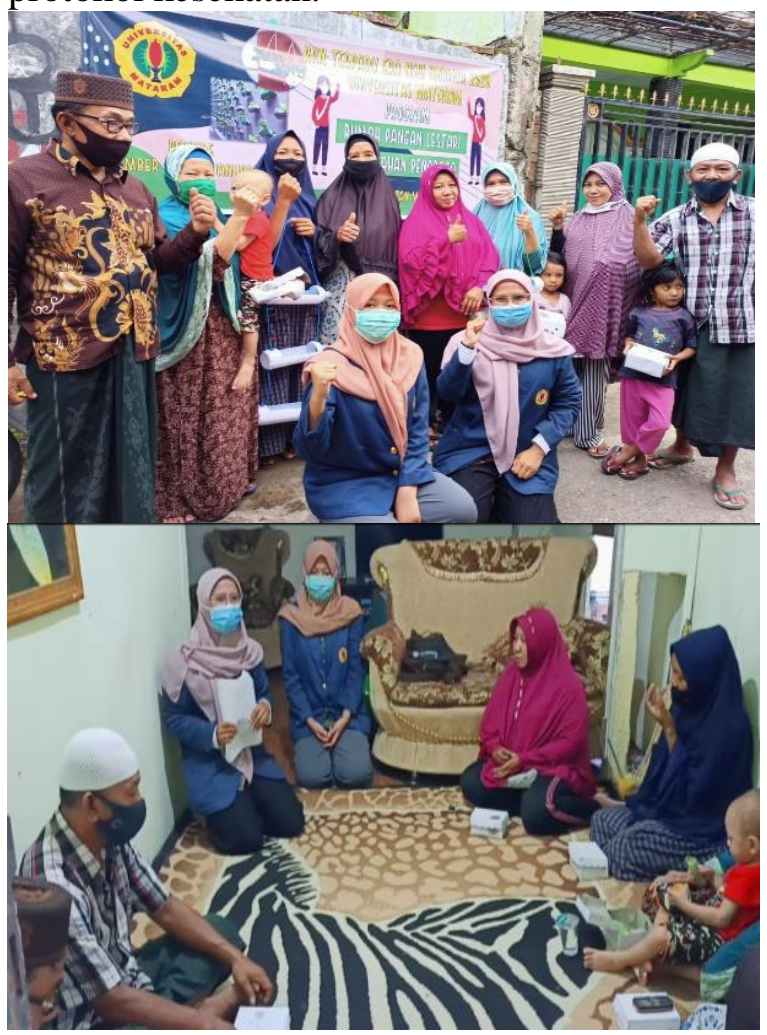

Gambar 8. Sosialisasi teknik vertikultur dengan mematuhi portokol kesehatan

\section{Kesimpulan}

Berdasarkan hasil yang didapatkan setelah melakukan serangkaian program, dari metode vertikultur diperkarangan rumah yang sempit sampai ke sosialisai covid-19. Dimana masyarakat menerima baik akan programprogram tersebut. Terbukti masyarakat mau mengikuti serangkaian kegiatan dari sosialisasi program vertikultur, pembuatan media tanam, menaman bibit pakcoy, dan dengan senang hati mau merawat tanaman vertikultur pakcoy di halaman rumahnya. Sehingga hasilnya bisa 
dirasakan oleh masyarakat itu sendiri, dan kebutuhan pangan dapat terbantu dengan adanya sayur organik hasil tanaman sendiri.

Sedangkan program covid-19 dibuktikan ketika ada kegiatan bersama, masyarakat tidak lupa untuk mematuhi protokol kesehatan. Seperti memakai masker yang baik, dan berjaga jarak.

\section{Ucapan Terima Kasih}

Terimakasih kepada FKIP Universitas Mataram, kemudian terimakasih juga kepada DPL kami yaitu Bapak Dr. Drs. Abdul Syukur, M. Si dan terakhir terimakasih juga kepada mitra kami yaitu Pengurus KRPL (Kelompok Rumah Pangan Lestari) Kelurahan Penaraga terkhusus pada RT 02 RW 03. Karena Atas bantuan dan bimbingannya, KKN Terpadu 2020 Program Rumah Pangan Lestari di Era New Normal ini dapat berjalan dengan lancar.

\section{Daftar Pustaka}

Mirani Zulfira, dkk. 2020. Bertanam Sayur pada Lahan Sempit Terbatas dengan Metode Vertikultur menggunakan Botol Bekas. Jurnal Pengabdian dan Pengembangan Masyarakat Politeknik Negeri Padang, Vol. 2 No. 2, December 2020, pp. 34-39.

Diwanti Dyah Pikanthi. 2018. Pemanfaatan Pertanian Rumah Tangga (Pekarangan Rumah) Dengan Teknik Budidaya Tanaman Sayuran Secara Vertikultur. Universitas Muhammadiyah Yogyakarta, Volume 1 Nomor 3.

Pujiati, dkk. 2017. Vertikultur Bawang Merah. Prodi Pendidikan Biologi FKIP Universitas PGRI Madiun. Cetakan-I 2017 ISBN : 978-602-74758-1-6. 